\title{
Aging with physical disabilities: experience intersected by stigma, social isolation and finitude
}

\author{
Envelhecer com deficiência física: experiência permeada pelo estigma, isolamento social e finitude \\ Envejecer con deficiencia física: experiencia permeada por el estigma, aislamiento social y finitud
}

\author{
José Alves Martins ${ }^{1}$ (i) \\ Miriam Aparecida Barbosa Merighi ${ }^{1}(\mathbb{C})$ \\ Maria Cristina Pinto de Jesus ${ }^{2}$ (I) \\ Helena Akemi Wada Watanabe ${ }^{1}($ [C)
}

1. Universidade de São Paulo.

São Paulo, SP, Brasil.

2. Universidade Federal de Juiz de Fora.

Juiz de Fora, MG, Brasil.

\section{Abstract}

Objective: To understand the experience from a perspective of elderly people with physical disabilities. Method: Qualitative study that interviewed 15 people from the Mato Grosso Association of Disabled Person. Testimonies were obtained from 2016 July to 2017 June in the metropolitan region of Cuiabá/Brazil. Data were organized in thematic categories and analyzed through social phenomenology of Alfred Schütz. Results: It was evidenced that the stigma intersects the experience of the physical deficiency including in the old age. The perpetuation of stigma translated into impaired identity, social isolation, lack of perspective and acceptance of finitude as inevitable, contributing to a negative experience in old age. Conclusion and implications for practice: The experience of aging with physical disability has an intrinsically multidimensional nature, confronting complex lives and social contexts hostile to the body diversity, which need to be considered in public policies, by service managers and professionals involved in the processes of care for the elderly with physical disability.

Keywords: Disabled Persons; Aging; Qualitative Research.

\section{Resumo}

Objetivo: Compreender a experiência de envelhecer na perspectiva de pessoas idosas com deficiência física. Método: Estudo de abordagem qualitativa que entrevistou 15 pessoas integrantes da Associação Mato-grossense de Deficientes. Os depoimentos foram obtidos de Julho/2016 a Junho/2017 na região metropolitana de Cuiabá/Brasil. Os dados foram organizados em categorias temáticas e analisados com base na fenomenologia social de Alfred Schütz. Resultados: Evidenciou-se que o estigma permeia a experiência da deficiência física inclusive na velhice. A perpetuação do estigma traduz-se em identidade deteriorada, isolamento social, ausência de perspectivas e aceitação da finitude como inevitável, contribuindo para uma experiência negativa na velhice. Conclusão e implicações para a prática: A experiência de envelhecer com deficiência física tem caráter intrinsecamente multidimensional, confrontando trajetórias de vidas complexas e contextos sociais hostis à diversidade corporal, os quais necessitam ser considerados nas políticas públicas, por gestores de serviços e profissionais envolvidos nos processos de cuidados à pessoa idosa com deficiência física.

Palavras-chave: Pessoas com Deficiência; Envelhecimento; Pesquisa Qualitativa.

\section{REsumen}

Objetivo: Comprender la experiencia de envejecer en la perspectiva de las personas ancianas con discapacidad física. Método: Estudio cualitativo en que se entrevistó a 15 personas integrantes de la Asociación Mato-grossense de Deficientes. Los testimonios fueron obtenidos de Julio/2016 a Junio/2017 en la región metropolitana de Cuiabá/Brasil. Los datos fueron organizados en categorías temáticas y analizados con base en el la Fenomenología social de Alfred Schütz. Resultados: Se evidenció que el estigma permea la experiencia de la discapacidad física incluso en la vejez. La perpetuación del estigma se traduce en identidad estropeada, aislamiento social, ausencia de perspectivas y aceptación de la finitud como inevitable, contribuyendo a una experiencia negativa en la vejez. Conclusión e implicaciones para la práctica: La experiencia de envejecer con discapacidad física tiene un carácter intrínsecamente multidimensional, enfrentando trayectorias de vidas complejas y contextos sociales hostiles a la diversidad corporal, los cuales necesitan ser considerados en las políticas públicas, por los administradores de servicios y profesionales involucrados en los procesos de atención a las personas ancianas con discapacidad física.

Palabras clave: Personas con Discapacidad; Envejecimiento; Investigación Cualitativa.
Corresponding Author: José Alves Martins.

E-mail: profze-alves@usp.br

Submitted on $04 / 28 / 2018$.

Accepted on 08/14/2018.

DOI: 10.1590/2177-9465-EAN-2018-0128 


\section{INTRODUCTION}

Survival increase of people with physical disability throughout the years makes them live sufficiently to reach old age. ${ }^{1}$ On the long run, the aging of people with physical disabilities should be differenciated of those who acquire incapacities as part of the aging process, due to the advances of his/her chronic condition, that is, aging with disability is not the same as disability due to aging associated with diseases, being only the first one the object of study. Frequently, these people have complex and multiple body alteration and functional limitations that can be caused by various secondary conditions, that threaten their longevity and challenge health care strategies. ${ }^{2}$

Currently, important movements on making greater efforts towards a society that is more sensitive to the needs of people with disabilities, and to the phenomenon of aging are observed, ${ }^{3}$ which are worldly perceived, but important gaps for investigation remain. ${ }^{4}$

Instituted in 2008, the United Nations Convention on the Rights of Persons with Disabilities' comprehension of disability reinforced as a priority for human rights and international socioeconomical development. ${ }^{5}$ In Brazil, the rights of people with disabilities were recognized by the Brazilian ratification of the referred convention, which means people who age with disabilities in Brazil do not just deserve the best care but they have the right to it.

Despite advances in the last decades, people with disabilities still have worse health prospects, lower levels of schooling, lower economic participation, higher poverty rates, lower life expectations and worse quality of life. ${ }^{6}$ As a consequence, people with disabilities are living longer, yet they face an accelerated aging process. ${ }^{7}$

Even though aging of people with disabilities is admittedly a good reason to celebrate, its challenging character should also be recognized. Because living longer with disability can subject these people to meaningful culmulative impacts on the chronic condition. Both conditions (disability and aging) can refer to dependency by a double charge of reduced mobility, once it can mean aging of a body already relatively functionally limited. Also doubly stigmatized, physical disability ${ }^{8}$ and aging ${ }^{9}$ both expresses in the body, suffer stigma in the society that values the perfect and productive body.

If for general population aging means over all to avoid physical incapacity and maintaining autonomy and independence, specially for self care, what to do say of aging in a body that is already relatively incapable and dependent?

There is few academic visibility on integral comprehension of coexistence and inter-relationship between aging and physical disability long term, once these conditions generally don't overlap on researches, policies and assistance practices. Both studies of social gerontology and those of disability tend to ignore the experience of aging with disabilities. ${ }^{10}$
This study aimed to comprehend the phenomenon of aging in the perspective of elderly people with physical disability.

National and international academic production present diverse research about physical disabilities and aging However there are few qualitative studies that discuss both of these themes together. ${ }^{4,11}$ Thus, to unveil this phenomenon, it is translated in a challenge that aims to wake the interest of academic community, managers, health professionals in the sense of evoking new lenses to construct care alternatives for people with physical disability.

\section{METHOD}

It's a qualitative research, in the theoretical perspective of social phenomenology by Alfred Schutz, which has as a principle to interpret the meaning of human action in the social world. ${ }^{12}$ The study was conducted using the theoretical assumptions: social world, intersubjective relationship and existential motivation (reasons why and reasons for) that help the understanding of social action, understood as the experience of aging in the perspective of elderly people with physical disabilities.

The study was done with elderly people members of the Disabilities Association of Mato Grosso (AMDE, portuguese Associação Matogrossense de Deficientes), located in the metropolitan region of Cuiabá (Brazil). AMDE is a philanthropic entity founded in 1983, of private rights, that aims socializing information and proposing, follow up and control public policies to people with disability, as well as promote cultural, sporting and scientific exchange.

The approach with the participants occurred gradually. There were two visits to AMDE, on meeting days to deal with general issues, where the researcher developed some dynamics and workshops with the associates, with the purpose of developing rapprochement, empathy and greater bond strength. At these meetings, they were informed about the research objectives, the right to participate and to withdraw at any time, if they feel uncomfortable, the confidentiality of each one's participation, as well as the need to sign the Free and Informed Consent Form.

Concomitant to this action, a search on the association's registration forms was performed to identify possible participants and locate their addresses, from the estabilished inclusion criteria. Afterwards, home searches were developed by the researcher, trying to find participants initially selected. When they were identified, a visit to their respective homes was scheduled.

The following inclusion criteria were used: people with congenital or acquired physical disability, of both sexes, age similar or over 60 years old, that acquired the dificiency before 40 and lived in community. The 40-year limit was set to exclude people who had experienced old age before living with physical disability. 
Phenomenological interview was used, with an average duration of 1 hour and 50 minutes. To conduct the interviews, the following guiding questions were used: tell me how your life is now, through the aging process. How do you grow old with physical disability? How do you perceive health services and care by the professionals? What do you expect for the future? In addition to the open questions, sociodemographic information was obtained to characterize the participants.

Data were collected by the reseacher, between the months of July/2016 and June/2017. According to the principles of the qualitative research the interviews were closed when the content emerged from the testimonies was sufficient for the understanding of the phenomenon studied. ${ }^{13}$

Interviews were recorded in an MP4 audio equipment, after participants' authorization. No testimony was excluded, totalizing 15 participants that were identified by numbers preceded by the letter I (participant) in a relationship of effective respect by the same and their manifestations.

Organization and analysis of testomonies were developed, according researchers of social phenomenology by Alfred Schütz. ${ }^{14}$ Interviews were transcribed and the content submitted to deep readings. Meanings were grouped in thematic categories that express lived experiences by elderly people with physical disability in the life world. Results were interpreted in the light of theoretical-methodological referential adopted and literature referred to the studied theme.

This study was approved by the feedback ํo 1854531 from Institutional Ethics Research Commitee of Health Public School of São Paulo University (FSP-USP) and followed the ethical and legal requirements involving human beings in consonance with the prescribed in the Resolution no 466 from December 12th 2012, from the National Health Council. ${ }^{15}$

\section{RESULTS}

Participants' profile were characterized by the predominance of the female, white, single, wheelchair user, with acquired disability, low education level, average income of 2,8 minimum wage, Catholic, age varied between 60 and 69 years old (average 62,8 ) and average experience time with disability of 47,9 years.

The set of categories of the study revealed the past and present experiences of elderly people with physical disabilities (reasons why), as well as their expectations in living with others in the social world (reasons for).

\section{Category 1 : Identity deteriorated by stigma (reasons why)}

In their verbalizations, participants highlighted that identity deteriorated by stigma is part of a smiliar conscience that influences their action in the social world:
[...] The crowd is around you, but you are alone like a scared animal because everyone looks at you a certain way, because we are different. I say that this is one of the saddest things of disability and doesn't matter the age, but when you are old it's worse. There's no way to handle this! No way!! [...] 18.

[...] There are people that look a certain way to us and it seems they are disgusted! I feel like this! [...] I feel people don't like us! [...] all my life I felt people don't like disabled people [...] today I think life isn't worth much because people don't respect us! [...] /12.

[...] sometimes, when I am in public and because I'm on a wheelchair, many look at me as if I couldn't be going to that place. It's sort of how it goes. 15

\section{Category 2: Social isolation (reasons why)}

It was notable among participants, the lack of enthusiasm to develop activities that need socialization with non disabled people, as observed in these fragments:

Sometimes, I exclude myself because if there's a place to go and I won't [go] because I know there are non-disabled people there and I am afraid of getting there and being excluded. So today I avoid leaving the house and only go to places there are people from my relationships, such as family members and old friends. But going out with strange people and without entanglement I don't go! I14

[...] It's very good to meet people like me. It's better yet because it's a place I feel good. Among disabled people there are none of those who look at you differently because you are disabled. 19

Home space is considered the first choice of this research's participants, as observed in the quotes:

[...] my house is my space and I don't want to leave there because outside I feel like those machines that bake chicken that the dogs are watching it. It's how I feel! 14

[...] here at home, when I see people getting ready to go out, I feel like going to but I can't! To me it's too difficult. . 112.

[...] today I don't leave the house anymore, that life of parties and tours is gone! It's all gone! Today I stay alone in the house! I13

[...] but most of the time, I stay in the house. I spend the whole day in the house! I read something, watch TV, these things [...] in the last days, my social life is much more recluse! $[\ldots] / 10$. 


\section{Category 3: Absence of perspectives and finitude (reasons for)}

It was apprehended through interviews, frequent absence of perspectives provoking changes in participants' emotional behavior, compromising life preservation sense and bringing them closer to the consciousness of their own finitude:

[...] my life doesn't have anything anymore, it doesn't have anything that matters. It's over! [...] when I feel that loneliness, I light a cigarette! I know I can't smoke, but as there is no reversion anymore to me, I smoke, because soon I'll die! I4.

Look! A person like me can't think of the future! A person like me must have conscience that is living the end of times. 111 .

But in the future, I don't think [...] the difference is that the non-disabled person see the thing for the future, ahead in time, and the person with disability only sees the current situation, looks below! [...] so we become a leaning person that has to prepare to die quietly in his place. 18

I don't have plans! None! I know I will be older each time. I think I won't last long! [...] in my future I don't think! Because I know my future! [...] 12.

[...] and at the age I am, I know I am taking life because I am passing the time! 16.

\section{DISCUSSION}

In the in-depth study of the phenomenon of the aging of people with physical disabilities, we identified internal and external elements of the experience of aging with physical disability that indicate that not all problems were related to age itself, but with recurrent physical, psychosocial and sociocultural aspects associated with aging.

The analysis of participants' testimonies unveiled that perpetuation of stigma as an important concrete category of the lived experience. It was evidenced that the stigma's lived experience permeates the experience of physical disability and it remains until old age, translating itself to deteriorated identity, social isolation and absence of perspectives, which contributes to these people's negative experiences at an old age.

It was evidenced that the impact of stigma influences various aspects of daily life and motivates the interpretation of being in relation to the world. In the lived past, the person with physical disability felt that his/her disability condition is evidenced in his/her body image and in the conception of this condition, which is negatively classified by the social group.

The nomination and interpretation of any body alterations is always a imminently social process. This way, the stigma doesn't represent only a personal attribute, which the person with disability constructs his/her subjectivation including at old age. ${ }^{16}$

According to social phenomenology by Alfred Schutz, this study's results point to a common self-description, structured in the archive of negative experiences, shared in the daily life, with difficult overcoming, and that perpetuates throughout the years. An intentional conscience constructed in the lived past and that projects at an old age, capable to deposit an depreciation judgement to the social coexistence. ${ }^{12}$

Other similar studies carried out in Brazil and in the world have also pointed to the experience of disability as a stigma. ${ }^{17,18}$

In a study about the identity dynamics of people with disabilities in Brazil and the United States of America, it was concluded that stigma is present in both cultures, reaffirming their universal character, regardless of these countries' social protection policies. ${ }^{17}$

An investigation that analyzed experiences described by people with physical disability, due to encephalic skull trauma sequelae, in the United Kingdom, revealed stigma perceived with potential loss of social status, together with meaningful chance in one's sense of identity. Social rejection resulted in disengagement and social withdrawal with potential emotional threats, having, from people, adopted strategies to evasion of social situations as a way to protect from stigma. ${ }^{18}$

Stigma was a meaningful typical trace in the process of aging of the researched group, which denotes a person marked by one characteristic that differs from what the society categorizes as "normal". This is the constant imbricated in the experience, overall by the visibility of a "different" body that interferes in their relationship network.

Disability is also an issue of continous identity management, once the daily life of the person with a disability is permeated by the development of individual characteristics one is recognized for. One recrutes elements of one's social world to stabilish and manage one's own identity that is translated in a dynamic process, constructed on daily social interactions, that changes according the relation with the compromised body and the excluding envirornment.

About daily social interactions, social phenomenology by Alfred Schutz, points that in the practical life, the person goes through a long chain of lived experiences. These experiences are exclusive of his, however they are constructed with material help and methods that are offered by other congeneres. This way, life's world is social and structured by the individual before his birth and this has a pressumption that it's given culturally. ${ }^{12}$

Based on the theoretical analysis of Schutz, the old person with disability occupies a position specifically devalued in the social group, structured in the deprecating view of the disabled body. A trajectory of prejudices and introjected discriminations, mainly by the visibility of the body that has accompanied it in the course of the times and that reflects in the longevity. 
Because it is an intersubjective world in which individuals coexist in a similar consciousness, understanding in this world occurs with reference to the other. ${ }^{12}$ For this understanding, structures and significations are given socially attributed to the body, which excludes any type associated with its opposite. The person who carries the stigma constructs his identity by comparing it with the others by reinforcing what was established as normal or natural in society, that is, the disability carries the stereotype of the deviation. ${ }^{16}$

It was identified in the present study, that the experience of aging with physical disability confront complex life journeys and hostile social contexts. Data pointed that the attitude by the social isolation, throught time, is incorporated to the daily life of these peoples in an automatized way, that is, without having a critical dimension about this attitude for understanding that it's inherent to the own condition. Self-will for confinement to the domestic space is embedded in a broader context of social relations as a consequence of rejection, damaging one's interpersonal relations.

The level of social isolation found in this research can be associated to identity deteriorated by the journey permeated by the constant presence of stigma. Commonly frequented spaces by non-disabled were considered unfavourable to the present study participants. Schutz's social theory, especially about the experience and intersubjective action in the lifeworld, asssures that the individual motivation is permeated by the context of social relationships. ${ }^{12}$

Pre-disposition by a lonely routine can be given in a virtue of external factors associated to a social envirornment hostile to body diversity that influences low motivation to shared contacts and thus the decision by the home withdrawal. The advancement of time was increased by the progression of home withdrawal, which for some participants caused even the loss of more reserved contacts, such as family and friends. Thus, by choosing friends and companions only in the context of disability, they have lost the ability to make new contacts, while at the same time weakening the possibility of building a more inclusive society.

Social isolation can generate important consequences. Social life marginal condition can produce individualization and a lonely journey of the path itself. Thus, they seek to adjust to the particular, disjointed conditions of common contact, where distancing increases social differences between disabled and non-disabled, contributing to the maintenance of stigma, since it does not face it.

In the experience of old age with physical disability, social isolation was also identified in a study developed in Quebec, Canada. It showed the existance of existing tensions among Canadian political guidelines and research participants' narratives that highlight the incapacity in late life was associated to the decrease of social engagement. ${ }^{10}$ Similarly, another study concluded that the perception of stigma is positively correlated with social avoidance among Chinese with disabilities. ${ }^{19}$
The present research identified that the state of social isolate which the person with disability is submitted to, overall in the late phase of life, contrast with the autonomy perspective and independence and promotes a disbelief in the future. Various statements showed the absence of perspectives in relation of one's own journey, in a context of functional capacity decline and facing the uncertainty in relation to the future that seems indiferent.

Participants' statements point to people who, impotent in the face of their inability to adapt to adversity, see the approach of old age as a threat to their quality of life and dignity. Clear absence of goals suggests that it's not about a new situation or a transition period, but permanent reduction of new perspectives.

For people with physical disability, aging showed itself as an adverse and threatening event of an already limited autonomy, being including present in some statements, the wish for life abbreviation as a way to avoid angst and loneliness. These cases were associated to people who live alone, as a fragile social network and high level of incapacity.

Present study's findings are associated to other studies that point out for a growing body of evidence associating old age to Ioneliness, depression and finity, denoting that it's about the terms that keep among themsevels relation to proximity. ${ }^{20,21}$

Investigation about physical disability and old age in the Brazilian northeast, concluded that these processes can be associated to the incapacity and suffering, due to a life of rebellion and profound angst, conceived as a difficult situation to be experienced..$^{20}$ Similar results were also found in a study that investigated eldery with disabilities in the southeast of Brazil. It point out that in the case of more disabled old people, giving up on life was accompanied of the perception of social support absence, mainly of family, the only resource recognized by them. Other older people have been categorical in associating old age with disease and tragedy, especially among those who have been least favored from a socio-economic point of view throughout life and continue to be so in old age. ${ }^{21}$

For present research's participants, death presented an important psychosocial meaning, in the eminence of limits in the capacity of control over its own destiny. The unwillingness to make plans for the future may represent the limit of pretensions in maintaining control over the outcomes of life itself.

In their discourses people with physical disability showed themselves impotent facing incapacities to new adaptations on adversity, renouncing new types of investments in relation to their needs, feeling more distant from the horizons of life, effectively incorporating the notion of finitude as part of the present life. Challenges facing the process of finitude can be faced in different ways for each person, depending the historic, cultural and social context in which is inserted, being associated to fear, anger, insecurity and impotence. ${ }^{22}$

The approximation of the ways in which the participants of this study relate to their longevity, allows to understand the 
intersubjective process of their experiences, in relation to an aging process with few possibilities. Perspective absence can be an intrinsic reflection of an adverse past, reflecting on the present and directing to the future. According to social phenomenology of Alfred Schutz, the flux of human action includes acts (past and present) and projects that translate expectations of the man in the social world. ${ }^{12}$

Even if finitude is constitutive part of human condition, present study's findings reveal important impact and evoke challenges and worries related to aging with physical disability, without planning for the future. This phenomenon comprehension can enable a better planning of rehabilitation services and social support, overall in adverse moments in life of people with physical disability.

Average of age (62 years old) relatively low among participants can be considered a limitation even though people with this age are considered elderly according to criteria from World Health Organization (over 60 years old). However, because they are interrelated to the body, the elderly may be more exposed to different clinical diseases, inherent in old age, including cognitive processes, which may constitute experiences different from those found in this study.

Fact of this research's participants are allocated in a determined community space, of a determined location, it doesn't enable conclusive generalizations, accoding qualitative analysis principals. Despite the limitations pointed out, the findings of the present study can be differentiated from other contexts, reinforcing that understanding the experience of aging with physical disability is particularly relevant to support the aging of these people.

\section{CONCLUSION AND IMPLICATIONS FOR PRACTICE}

This study enabled to comprehend that the experience of aging with physical disability has a multidimensional character intrinsically, that confront complex life journeys and hostile social contexts to body diversity.

An important aspect is that this person experiences stigma in a constant form, that remains until the last phase of life with a strong impact about his self-esteem and self-acceptance. The unwillingness to overcome stigma projected in his old age is permeated by social isolation, absence of life perspective and acceptance of finitude as inevitable. This situation translates a negative experience of old age of the person with physical disability generator of suffering.

The meanings of the participants' subjective experiences, analyzed in social contexts in the light of Schutz's social phenomenology, point out that the conflicts arising from the experience of aging with physical disability do not derive exclusively from the advances of functional physical decline, but from those with the adverse social environment that represents a threat to the continuity of social role performance as time goes by.
We expect this study's results can contribute to formulate public policies and services' managers, as well as professionals involved in caring process destined to people with physical disability, overall the oldest ones, waking for the development of strategies that stimulate resistance to stigma and overcoming social devaluation. Disseminating the social conception of disability, improving positive self-perception, promoting a culture of bodily diversity, supporting legal means to respond to human rights violations and forms of discrimination, among others are examples of such actions.

\section{REFERENCES}

1. Molton IR, Yorkston KM. Growing Older With a Physical Disability: A Special Application of the Successful Aging Paradigm. J Gerontol B Psychol Sci Soc Sci [Internet]. 2017 Mar; [cited 2017 Aug 4]; 72(2):2909. Available from: https://www.ncbi.nlm.nih.gov/pubmed/27702838

2. Orlin MN, Cicirello NA, O'Donnell AE, Doty AK. The continuum of care for individuals with lifelong disabilities: role of the physical therapist. Phys Ther [Internet]. 2014 Jul; [cited 2017 Feb 12]; 94(7):1043-53. Available from: https://www.ncbi.nlm.nih.gov/pubmed/24557656

3. Heller T, Fisher MPH, Marks B, Hsieh K. Interventions to promote health: crossing networks of intellectual and developmental disabilities and aging. Disabil Health J [Internet]. 2014 Jan; [cited 2018 Jan 8]; 7(1 Suppl):S24-32. Available from: https://www.ncbi.nlm.nih.gov/ pubmed/24456681

4. Putnam M, Molton IR, Truitt AR, Smith AE, Jensen MP. Measures of aging with disability in U.S. secondary data sets: Results of a scoping review. Disabil Health J [Internet]. 2016 Jan; [cited 2017 Feb 23]; 9(1):510. Available from: https://www.ncbi.nlm.nih.gov/pubmed/26341578

5. United Nations. Convention on the Rights of Persons with Disabilities (CRPD). New York: United Nations [Internet]; 2006. [cited 2017 Jan 3]. Available from: https://www.un.org/development/desa/disabilities/ convention-on-the-rights-of-persons-with-disabilities.html

6. Rodakowski J, Skidmore ER, Anderson SJ, Begley A, Jensen MP, Buhule OD, et al. Additive effect of age on disability for individuals with spinal cord injuries. Arch Phys Med Rehabil [Internet]. 2014 Jun; [cited 2017 Mar 2]; 95(6):1076-82. Available from: https://www.ncbi.nlm.nih. gov/pubmed/24530841

7. Smith AE, Molton IR, Jensen MP. Self-reported incidence and age of onset of chronic comorbid medical conditions in adults aging with long-term physical disability. Disabil Health J [Internet]. 2016 Jul [cited 2017 May 12]; 9(3):533-8. Available from: https://www.ncbi.nlm.nih.gov/ pubmed/27009420

8. Grue J. The social meaning of disability: a reflection on categorisation, stigma and identity. Sociol Health IIIn [Internet]. 2016 Jul [cited 2017 Apr 8]; 38(6):957-64. Available from: https://www.ncbi.nlm.nih.gov/ pubmed/27363597

9. Peres RJ, Espírito-Santo G, Espírito FR, Ferreira NT, Assis MR. Insatisfação com a imagem corporal entre pessoas com deficiência visual. Rev Bras Ciênc Esporte [Internet]. 2015 Sep [cited 2017 Dec 5]; 37(4):362-6. Available from: http://www.scielo.br/pdf/rbce/v37n4/01013289-rbce-37-04-0362.pdf

10. Raymond E, Grenier A, Hanley J. Community Participation of Older Adults with Disabilities. J Community Appl Soc Psychol [Internet] 2014 Jan [cited 2017 Dec 12]; 24(1):50-62. Available from: https:// onlinelibrary.wiley.com/doi/pdf/10.1002/casp.2173

11. McGrath C, Laliberte Rudman D, Polgar J, Spafford MM, Trentham B. Negotiating 'positive' aging in the presence of age-related vision loss (ARVL): The shaping and perpetuation of disability. J Aging Stud [Internet].2016 Dec [cited 2018 Jan 26]; 39:1-10. Available from: https:// www.ncbi.nlm.nih.gov/pubmed/27912847

12. Schutz A. Estudios sobre teoría social: escritos II. Traducción de Néstor Míguez. 2ª ed. Buenos Aires: Amorrortu; 2012. 
13. Minayo MCS. Amostragem e saturação em pesquisa qualitativa: consensos e controvérsias. Rev Pesq Qual [Internet]. 2017 Apr [cited 2017 Nov 11]; 5(7):1-12. Available from: http://rpq.revista.sepq.org.br/ index.php/rpq/article/view/82/59

14. Jesus MCP, Capalbo C, Merighi MAB, Oliveira DM, Tocantins FR, Rodrigues BMRD, et al. The social phenomenology of Alfred Schütz and its contribution for the nursing. Rev Esc Enferm USP [Internet]. 2013 Jun [cited 2017 Aug 26]; 47(3):728-33. Available from: http://www.scielo.br/ scielo.php?script=sci_arttext\&pid=S0080-62342013000300736

15. Ministério da Saúde (BR). Conselho Nacional de Saúde. Resolução ${ }^{\circ}$ 466 de 12 de dezembro de 2012. Dispõe sobre as Diretrizes e Normas Regulamentadoras de Pesquisas com Seres Humanos [Internet]. Brasília: Diário Oficial da União; 2012 [Internet]. [cited 2018 Feb 7]. Available from: http://conselho.saude.gov.br/resolucoes/2012/reso466. pdf

16. Martins BS. A reinvenção da deficiência: novas metáforas na natureza dos corpos. Fractal Rev Psicol [Internet]. 2015 Sep-Dec [cited 2017 Mar 9]; 27(3):264-71. Available from: http://www.scielo.br/pdf/fractal/ v27n3/1984-0292-fractal-27-3-0264.pdf

17. Moreira LB, Cappelle MCA, Carvalho-Freitas MN. A dinâmica identitária de pessoas com deficiência: um estudo no Brasil e nos Estados Unidos. RAM Rev Adm Mackenzie [Internet]. 2015 Jan-Feb [cited 2017 May 22]; 16(1):40-61. Available from: http://www.scielo.br/pdf/ram/v16n1/15186776-ram-16-01-0040.pdf
18. Freeman A, Adams M, Ashworth F. An exploration of the experience of self in the social world for men following traumatic brain injury. Neuropsychol Rehabil [Internet]. 2015 Sep-Dec [cited 2018 Feb 27]; 25(2):189-215. Available from: https://www.ncbi.nlm.nih.gov/ pubmed/24848538

19. Zhang L, Li W, Liu B, Xie W. Self-esteem as mediator and moderator of the relationship between stigma perception and social alienation of Chinese adults with disability. Disabil Health J [Internet]. 2014 Jan [cited 2017 Nov 13]; 7(1):119-23. Available from: https://www.ncbi.nlm.nih.gov/ pubmed/24411516

20. Valença TDC, Santos WS, Lima PV, Santana ES, Reis LA. Deficiência física na velhice: um estudo estrutural. Esc Anna Nery [Internet]. 2017 Sep [cited 2018 Jan 29]; 21(1):e20170008. Available from: http://www. scielo.br/pdf/ean/v21n1/1414-8145-ean-21-01-e20170008.pdf

21. Pereira JK, Giacomin KC, Firmo JOA. Funcionalidade e incapacidade na velhice: ficar ou não quieto? Cad Saúde Pública [Internet]. $2015 \mathrm{Jul}$ [cited 2017 Oct 3]; 31(7):1451-9. Available from: http://www.scielo.br/

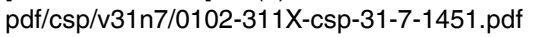

22. Marinho VT, Costa ICP, Andrade CG, Santos KFO, Fernandes MGM, Brito FM. Percepção de idosos acerca do envelhecimento ativo. Rev Enferm UFPE [Internet]. 2016 May [cited 2017 Aug 15]; 10(5):1571-8. Available from: https://periodicos.ufpe.br/revistas/revistaenfermagem/ article/viewFile/11151/12663 